Article

\title{
Effects of Drought and Heat on Photosynthetic Performance, Water Use and Yield of Two Selected Fiber Hemp Cultivars at a Poor-Soil Site in Brandenburg (Germany)
}

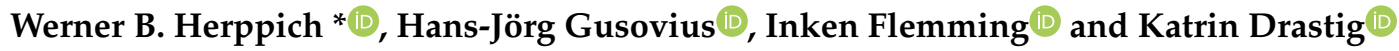 \\ Leibniz Institute for Agricultural Engineering and Bioeconomy (ATB), Max-Eyth-Allee 100, 14469 Potsdam, \\ Germany; hjgusovius@atb-potsdam.de (H.-J.G.); inkenflemming@t-online.de (I.F.); \\ kdrastig@atb-potsdam.de (K.D.) \\ * Correspondence: wherppich@atb-potsdam.de; Tel.: +49-331-5699-620
}

Received: 3 August 2020; Accepted: 9 September 2020; Published: 10 September 2020

check for updates

\begin{abstract}
Hemp currently regains certain importance as fiber, oil and medical crop not least because of its modest requirements of biocides, fertilizer and water. During recent years, crops were exposed to a combination of drought and heat, even in northern Central-Europe. Dynamic responses of photosynthesis and stomatal conductance to these stresses and their persistent effects had been studied, if at all, in controlled environment experiments. Comprehensive field studies on diurnal and long-term net photosynthesis and gas exchange, and yield properties of hemp during a drought prone, high-temperature season in northern Central-Europe are obviously missing. Thus, in whole season field trails, the essential actual physiological (rates of net photosynthesis and transpiration, stomatal conductance, water use efficiencies, ambient and internal $\mathrm{CO}_{2}$ concentrations) and the yield performance of modern high-yielding multi-purpose hemp cultivars, 'Ivory' and 'Santhica 27', were evaluated under extreme environmental conditions and highly limited soil water supply. This provides comprehensive information on the usability of these cultivars under potential future harsh production conditions. Plants of both cultivars differentially cope with the prevailing climatic and soil water conditions. While 'Ivory' plants developed high rates of $\mathrm{CO}_{2}$ gain and established large leaf area per plant in the mid-season, those of 'Santhica 27' utilized lower $\mathrm{CO}_{2}$ uptake rates at lower leaf area per plant most time. This and the higher germination success of 'Santhica 27 ' resulted in nearly twice the yield compared to 'Ivory'. Although stomatal control of $\mathrm{CO}_{2}$ gain was pronounced in both cultivars, higher stomatal limitations in 'Ivory' plants resulted in higher overall intrinsic water use efficiency. Cultivation of both hemp cultivars with only basic irrigation during seed germination was successful and without large effects on yield and quality. This was valid even under extremely hot and dry climatic conditions in northern Central Europe.
\end{abstract}

Keywords: climate change; intrinsic water use efficiency; stomatal conductance; stomatal limitations; transpiration; water productivity

\section{Introduction}

Hemp (Cannabis sativa L.) is a sustainable, high-yielding, multi-purpose crop (biomass, fiber, woody shives, seed-oil, nutritional products for biomedical and pharmaceutical uses and energy; [1-6]). It requires no biocide, has limited demands with respect to fertilizer usage $[5,6]$ and crop rotation, but is recommended as intermediate crop for rotation in food-crop production systems [7]. Generally, hemp is known to have a positive impact on the environment $[2,8-10]$. 
In recent years, optimal cultivation conditions and their dependence on various environmental (irradiation, photoperiod, temperature; e.g., [5,11]), production (plant density, mineral nutrition and irrigation regime; e.g., [1,12] and genetic conditions $[13,14]$ have been intensively investigated especially for fiber hemp $[2,4-6,15]$. In this context, particular emphasis was laid on the effects of nitrogen supply $[3,6,12,16]$, but also irrigation demands $[1,17-20]$ of plant growth, and fiber yield and quality.

According to Gao et al. [13], drought is assumed to have the largest impact on crop culture and world agriculture among all relevant abiotic stressors. Besides extreme weather events, frequencies of water shortages or droughts will currently further increase due to the effects of global warming, worldwide. Thus, irrigation may probably become indispensable for overcoming prolonged water shortages and for obtaining optimum yield in hemp production in most regions of the world [20]. Studies in Europe indicated that hemp plants require a total of 500-700 $\mathrm{mm}$ water for development, with at least 250-300 mm during the vegetative growth phase [18]. Especially in Southern Mediterranean regions, with their high evaporative demands, between 250 and $450 \mathrm{~mm}$ of additional water may be necessary, while water consumption may vary between 200 and $300 \mathrm{~mm}$ in less drought prone areas [17]. Furthermore, a comparative study on monoecious and dioecious hemp cultivars in semi-arid Mediterranean environments [19] concluded that at least $250 \mathrm{~mm}$ of irrigation water were needed for monoecious early genotypes, while dioecious late cultivars require $450 \mathrm{~mm}$.

On the other hand, Amaducci et al. [17] indicated that irrigation only slight improved yields of biomass $(7 \%)$ and stem mass $(9 \%)$. These authors also stated that irrigation effects were lower for hemp than e.g., in maize or kenaf. Similarly, yields of the hemp cultivar 'Futura 75 ' plants were only significantly affected when irrigation was reduced to $25 \%$ restitution of potential maximum evapotranspiration (ETm) [19]. Similarly, hemp plants showed good yields in terms of stem and bark dry mass when up to $66 \%$ of the available water was restored, corresponding to a seasonal water consumption of 410-460 $\mathrm{mm}$ in Southern Europe [20].

These obviously contrasting findings and interpretations indicate that the basic physiological and ecophysiological knowledge on the complex and interactive effects of the various environmental factors is still incomplete. Only recently, results of several comprehensive studies on photosynthetic performance and gas exchange properties, and their responses to variations in nitrogen supply $[5,16,21]$, temperature [5,19,22], photosynthetic photon flux rates [22,23] and/or ambient $\mathrm{CO}_{2}$ concentration [22,24] and soil water availability $[5,21,24]$ were published. These investigations were either performed in fully controlled environments or, if real field investigations, their analyses were mainly based on well-established biochemical modelling.

Thus, information on the effects of low soil water availability and, particularly, its interaction with high temperatures and high irradiation on photosynthesis, water use efficiency, and growth and yield of multi-purpose industrial hemp cultivars is scarce. Little attention has been paid to understanding the physiological basis of the high resource-use efficiency of hemp $[5,21]$. In this context, comprehensive field investigations are obviously missing.

In field trails, gas exchange (rates of net photosynthesis and transpiration, stomatal conductance, instantaneous and intrinsic water use efficiency, ambient and internal $\mathrm{CO}_{2}$ concentrations) and relevant climatic parameters (temperature, water vapor saturation deficit, solar radiation, photosynthetic photon flux rates and precipitation) were measured during the whole course of a growing season in parallel with growth and, finally, yield analyses. This study was performed without additional regular irrigation throughout the growing season during an exceptionally dry, hot and sunny summer period (2018) on an experimental field close to Potsdam, the capital of the federal state of Brandenburg, Germany. This area is well-known for its sandy soils. With a long-term mean annual precipitation of less than $410 \mathrm{~mm}$, it ranks among the driest regions in Germany and Europe [25]. Thus, this investigation evaluates the intrinsic physiological and the actual yield performance of two high-yielding multi-purpose hemp cultivars under extreme environmental conditions and highly limited soil water supply. This will provide valuable information on their usability under potential future harsh production conditions. 


\section{Materials and Methods}

\subsection{Site Description}

The experiments were performed at the 'open fieldlab for digital agriculture' [26] of the Leibniz Institute for Agricultural Engineering and Bioeconomy, situated in Marquardt ( $\left.52^{\circ} 28^{\prime} 2^{\prime \prime} \mathrm{N}, 12^{\circ} 57^{\prime} 39^{\prime \prime} \mathrm{E}\right)$ near Potsdam (Germany). While the topsoil primary consists of low to average silty sands (sands: 71-88\%; silt: $8-15 \%$; clay: $4-14 \%$; $C_{\text {org }}$ : $0.4-1.7 \%$; soil texture: Ss, Su, St, SI2, SI4), the area is generally characterized by weakly loamy sands $[27,28]$. Both are characterized by limited water holding (field capacity: $26.5 \pm 0.7 \%$; permanent wilting point: $8.2 \pm 0.5 \%$ ( $v / v$; soil water content); usable field capacity: $\mathrm{XXXX)}$ and cation exchange capacities, and, thus, low fertility (soil number: 0-34; $\mathrm{pH}$ : 6.6-8.4).

\subsection{Climatic Parameters}

Hourly and daily values of precipitation $(p)$ were measured with a Hellmann-type tipping bucket rain gauge (ECRN-100, Meter Group, Inc., Pullman, DC, USA). At the Marquardt research site at a distance of $120 \mathrm{~m}$ to the study area, climate data was obtained at hourly resolution with a digital network-compatible weather station (UNIKLIMA vario, TOSS, Intelligente Meßtechnik und Automatisierung $\mathrm{GmbH}$, Potsdam, Germany). Among others, it comprises a combined air temperature/air humidity LT1/RMF Uniklima sensor, a BGV solar radiation sensor (spectral range 380-1100 nm, max. sensitivity at ca. $780 \mathrm{~nm}$ and a rapid drop thereafter) and a BARO2 air pressure sensor (all TOSS).

\subsection{Plant Material, Growth Conditions and Experimental Design}

Admitted as a multi-purpose, low-THC (Tetrahydrocannabinol) industrial hemp cultivar in the EU and Switzerland since 2013, the mid-mature monoecious [29] French 'Santhica 27' is widely used in Europe for fiber production. The monoecious Dutch cultivar 'Ivory', also characterized by a low THC content $(<0.2 \%)$, was relatively recently bred from the early-mature dioecious cultivar 'Chameleon' [19] for improved germination, grain yield and rettability. 'Santhica 27 ' and 'Ivory' were representatively chosen from a large variety of cultivars, tested in the MultiHemp EU project (Multipurpose hemp for industrial bioproducts and biomass; grant agreement number 311849).

Plants of 'Santhica 27' were sown on 4 May 2018 on $1188 \mathrm{~m}^{2}$ (0.12 ha) in total. Those of 'Ivory' were sown two weeks later on $792 \mathrm{~m}^{2}$ (0.08 ha), both with a density of 200 seeds per $\mathrm{m}^{2}$. For analyses and rating, three distinct experimental plots $(0.5 \mathrm{~m} \times 0.5 \mathrm{~m})$ each were randomly chosen and marked in these areas, two weeks after sowing.

The soil was finally cultivated with a tiller two days before the initial sowing. $\mathrm{N}$ fertilization (calcium ammonium nitrate) was at $70 \mathrm{~kg} \mathrm{ha}^{-1}$. In May, $55 \mathrm{~kg}$ kieserite $\left(\mathrm{MgSO}_{4} \cdot \mathrm{H}_{2} \mathrm{O}\right)$ was applied. Due to the low precipitation during seed germination and seedlings development, the study area was once irrigated on the 30 May 2018 with $10 \mathrm{~mm}$ using sprinkler irrigation to assure sprouting. Plants of both cultivars were harvested on 19 September 2018.

\subsection{Leaf Area Index and Plant Yields}

From 15 June 2018 until harvest, growth parameters of plants of each cultivar were obtained by visual inspection. The leaf area index ( $L A I)$ was measured at weekly intervals on both the total cultivation areas and on the specific plots. For $L A I$, leaves of small, medium-sized and large plants each were harvested, scanned with a commercial flatbed scanner (Epson Perfection V700 Photo Scanner, EPSON Deutschland GmbH, Meerbusch, Germany) and their area analyzed with the software GNU Image Manipulation Program 2.10.14 [30]. From the mean leaf area of plants on the specific plots, the average $L A I\left(\mathrm{~m}^{2} \mathrm{~m}^{-2}\right)$ of plants of each cultivar was calculated.

For growth analyses, the height of ten plants and the total number of plants were determined on all experimental plots and mean growth rates calculated during the entire vegetation period. For total mass yield, all plants on the specific inspection plots were separately cut by hand, sorted, their fresh 
mass obtained, oven-dried (at $105^{\circ} \mathrm{C}$ ) to constant mass (for approx. $24 \mathrm{~h}$ ) and their dry mass weighed on 18 September 2018.

\subsection{Analyses of Gas Exchange}

Transpiration and $\mathrm{CO}_{2}$ exchange were measured with a portable $\mathrm{CO}_{2} / \mathrm{H}_{2} \mathrm{O}$ gas exchange system (Ciras-1, PP Systems Europe, Hitchin, UK) on 22 dates during 17 weeks of the growing season. Leaves (three single leaves per four plants per plot) were inserted in the climatized (temperature, air humidity and photosynthetic photon flux rate-control) Parkinson PLC 4 leaf cuvette (PP Systems Europe, Hitchin, UK) with a total measuring area of $2.5 \mathrm{~cm}^{2}$. At the extreme climatic conditions in 2018, leaf temperature, as measured with an infrared sensor incorporated in the PLC, was kept close to ambient $\left(29.6 \pm 3.6^{\circ} \mathrm{C}\right.$ and $27.0 \pm 2.5^{\circ} \mathrm{C}$ for 'Santhica' and 'Ivory' plants, respectively). With a PP Systems LED (blue plus red) lighting attachment, photosynthetic photon flux rates (PPFR) of approx. $1100 \pm 55 \mu \mathrm{mol} \mathrm{m}{ }^{-2} \mathrm{~s}^{-1}$ were obtained at top of the cuvette.

The recorded gas exchange data ( $T_{\text {leaf, }}$, gas flow rate, $\mathrm{CO}_{2}$ and water vapor concentration at ambient and in the cuvette) were used to calculate rates of transpiration $\left(J_{\mathrm{H} 2 \mathrm{O}}, \mathrm{mmol} \mathrm{m}^{-2} \mathrm{~s}^{-1}\right)$ and net $\mathrm{CO}_{2}$ exchange $\left(J_{\mathrm{CO} 2}, \mu \mathrm{mol} \mathrm{m} \mathrm{m}^{-2} \mathrm{~s}^{-1}\right)$, stomatal conductance for water vapor diffusion $\left(g_{\mathrm{st}}, \mathrm{mmol} \mathrm{m}^{-2} \mathrm{~s}^{-1}\right)$ and internal $\mathrm{CO}_{2}$ molar fraction $\left(c_{\mathrm{i}}\right)$ after von Caemmerer and Farquhar [31] as summarized by Matyssek and Herppich [32]. Because not all measured leaves showed the same area, $J_{\mathrm{CO} 2}$ and $J_{\mathrm{H} 2 \mathrm{O}}$ were always corrected for the true inserted leaf area as determined afterwards. From the above rates, $g_{\text {st }}$ and the $\mathrm{CO}_{2}$ mole fraction of the ambient air ( $c_{\mathrm{a}}$, regular output parameter of the CIRAS), $c_{\mathrm{i}}$ and both the instantaneous (WUE $E_{\text {inst }}=J_{\mathrm{CO} 2} J_{\mathrm{H} 2 \mathrm{O}}{ }^{-1}, \mathrm{mmol} \mathrm{mol}^{-1}$ ) and the intrinsic water use efficiency, $\left(W U E_{\text {intrinsic }}=J_{\mathrm{CO} 2} g_{\mathrm{st}}{ }^{-1}, \mathrm{mmol} \mathrm{mol}^{-1}\right)$ were calculated [32].

\subsection{Statistical Analysis}

Statistical analyses (ANOVA) were performed with WinSTAT (R. Fitch Software, Staufen, Germany). When results were presented as means \pm standard deviation (SD), the significance of differences between means was evaluated with Duncan's multiple range test $(p<0.05)$.

\section{Results}

\subsection{Climatic Condition during the Growing Season}

For the meaningful interpretation of the variations of overall plant responses, the exact knowledge of the climatic condition during the growing season is indispensable (Figure 1). During the entire period from early May until end of October, the climate could be characterized as sunny (Figure 1a), hot (Figure 1b) and dry (Figure 1d). In May, maximum solar irradiation, as measured with a solar radiation sensor, ranged between 740 and $1000 \mathrm{~J} \mathrm{~m}^{-2} \mathrm{~s}^{-1}$, but never fell below $600 \mathrm{~J} \mathrm{~m}^{-2} \mathrm{~s}^{-1}$; with daily means ranging between 220 and $280 \mathrm{~J} \mathrm{~m}^{-2} \mathrm{~s}^{-1}$ (Figure 1a). During mid-June to early July and again in August, maximum solar irradiation regularly exceeded $1000 \mathrm{~J} \mathrm{~m}^{-2} \mathrm{~s}^{-1}$, reaching highest values of more than $1200 \mathrm{~J} \mathrm{~m}^{-2} \mathrm{~s}^{-1}$ in June. During the entire production period, only seven days were, at least partially, overcast as indicated by maximum solar irradiation of less than $550 \mathrm{~J} \mathrm{~m}^{-2} \mathrm{~s}^{-1}$. To mimic this high radiation input, the mean photosynthetic photon flux rates were kept at approx. $1100 \mu \mathrm{mol} \mathrm{m} \mathrm{m}^{-2} \mathrm{~s}^{-1}$ during gas exchange measurements, except for one day, when PPFR was reduced for technical reasons.

On several days, maximum air temperature $\left({ }^{\max } T_{\text {air }}\right)$ clearly exceeded $35^{\circ} \mathrm{C}$, while means of ${ }^{\max } T_{\text {air }}$ were higher than $29^{\circ} \mathrm{C}$ in July and August (Figure $1 \mathrm{~b}$ ), and still nearly $24^{\circ} \mathrm{C}$ in October. This very long hot period was only rarely interrupted by few moderate and even cool and humid days (Figure 1c), which reflected the 13 rainy days (Figure 1d). However, total precipitation during the entire growing season was only $56 \mathrm{~mm}$ and daily maximum never exceeded $16 \mathrm{~mm}$. 

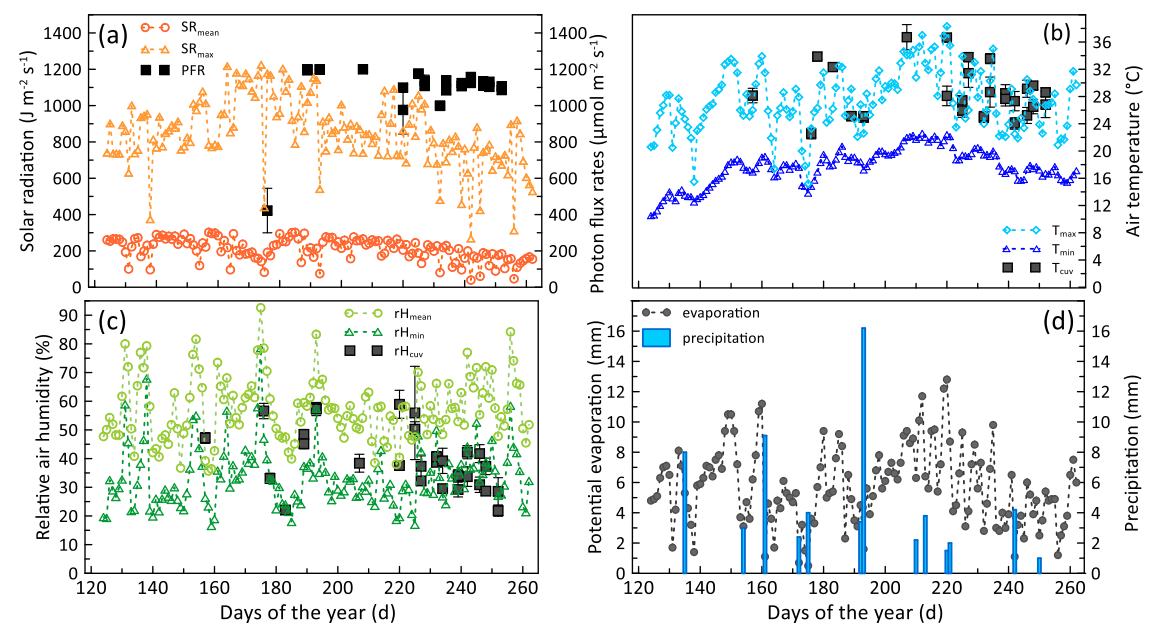

Figure 1. Climatic condition during the growing season. (a) Mean (circles) and maximum (triangles) daily energy flux rates of solar radiation $\left(S R, \mathrm{~J} \mathrm{~m}^{-2} \mathrm{~s}^{-1}\right)$ and photosynthetic photon flux rate $(P F R, \mu \mathrm{mol}$ $\mathrm{m}^{-2} \mathrm{~s}^{-1}$ ) on top of the gas exchange leaf cuvette (filled squares). (b) Daily minimum and maximum air temperature $\left({ }^{\circ} \mathrm{C}\right)$ and temperature of leaves in the cuvette $\left({ }^{\circ} \mathrm{C}\right) .(\mathrm{c})$ Minimum and maximum values of relative air humidity $(\mathrm{rH})$ measured in the gas exchange cuvette. (d) Daily values of pan evaporation (filled circles) and total precipitation (bars).

\subsection{Daytime Gas Exchange Characteristics of 'Santhica 27' Plants}

On a dry, hot and high radiation day, net $\mathrm{CO}_{2}$ exchange (Figure 2a) showed a pronounced peak during the morning. It started to decline around noon, well before radiation was maximum (Figure $2 b$ ) to reach low and almost constant rates during the afternoon. Few leaves were obviously photoinhibited and switched to net $\mathrm{CO}_{2}$ losses, i.e., respiration. For the gas exchange measurements, hemp leaves of different insertion heights and developmental stages were used because the study aimed to evaluate the actual range of plant performance. This fact easily explains the high variability of results of net photosynthesis (Figure 2a) and photosynthetic photon flux rates (Figure 2b).

The transpiration $\left(\mathrm{J}_{\mathrm{H} 2 \mathrm{O}}\right)$ and the stomatal conductance of the hemp leaves tended to increase until short before noon. Then it slowly decreased to low and nearly constant rates during the afternoon (Figure $2 \mathrm{c}, \mathrm{d})$, similar to net the $\mathrm{CO}_{2}$ exchange $\left(J_{\mathrm{CO} 2}\right)$. Variability of these results then became pronouncedly smaller. Leaf temperature and water vapor partial pressure deficit showed the same diurnal dynamics (Figure 2e,f). They rapidly increased till noon and, much slower, reached a maximum in the afternoon. The parallelity of the changes of these parameters clearly reflected that the absolute air humidity was nearly constant on this day. Indeed, the dew point only ranged between ca. $14.4^{\circ} \mathrm{C}$ in the morning and $15.3^{\circ} \mathrm{C}$ in the evening (data not shown).

While the ratio of internal to ambient $\mathrm{CO}_{2}$ molar fraction $\left(c_{\mathrm{i}} / c_{\mathrm{a}}\right)$ was relatively constant at approx. 0.6 in the morning (Figure 2g), it tended to decline and became much more variable in the afternoon. The pronounced influence of stomatal conductance on net photosynthesis is also highlighted by the plot of $J_{\mathrm{CO} 2}$ versus $g_{\text {st }}$ (Figure $2 \mathrm{j}$ ). In fact, this plot emphasized two effects. At first, the reduction of net $\mathrm{CO}_{2}$ uptake is due to an increased resistance to water vapor transfer as a result of reduced stomatal opening; secondly, some few leaves are clearly photoinhibited because $J_{\mathrm{CO} 2}$ declined while $g_{\text {st }}$ remained high (Figure 2j). 

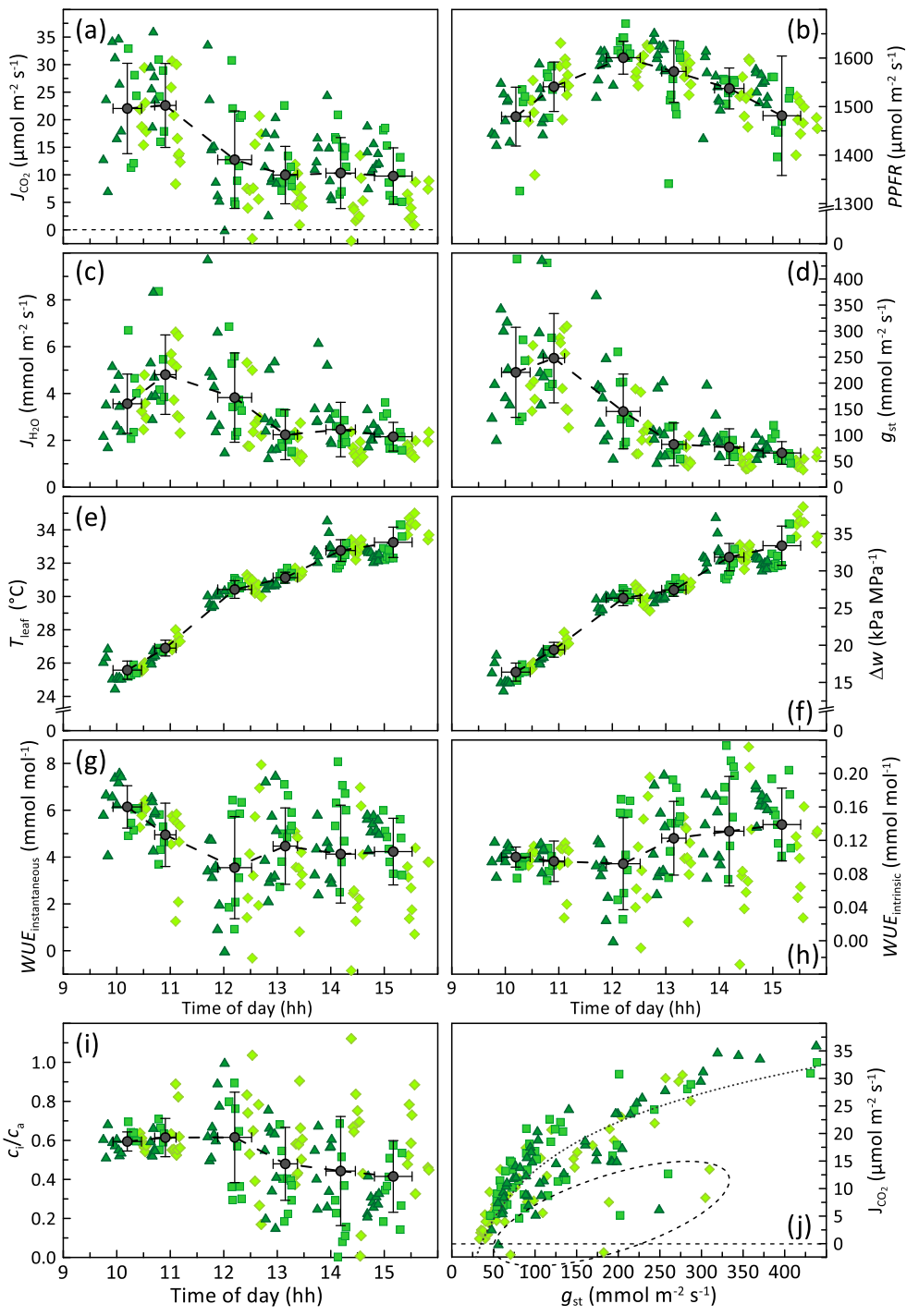

Figure 2. Diurnal variation of (a) net $\mathrm{CO}_{2}$ exchange $\left(\mathrm{J}_{\mathrm{CO} 2}\right)$, (b) photosynthetic photon flux rates (PPFR), (c) transpiration $\left(J_{\mathrm{H} 2 \mathrm{O}}\right),\left(\right.$ d) stomatal conductance for water vapor transfer $\left(g_{\mathrm{st}}\right),(\mathbf{e})$ leaf temperature $\left(T_{\text {leaf }}\right),(\mathbf{f})$ water vapor partial pressure deficit $(\Delta \mathrm{w}),(\mathbf{g})$ instantaneous $\left(W U E_{\text {inst }}\right),(\mathbf{h})$ intrinsic water use efficiency $\left(W U E_{\text {intrinsic }}\right)$, (i) ratio of internal $\left(c_{\mathrm{i}}\right)$ to ambient $\mathrm{CO}_{2}$ molar fraction $\left(c_{\mathrm{a}}\right)$ and $(\mathbf{j})$ plot of $J_{\mathrm{CO} 2}$ over $g_{\text {st }}$ of 'Santhica 27 ' leaves, measured on three (squares, triangles, diamonds) plots $(0.5 \mathrm{~m} \times 0.5 \mathrm{~m})$ and the respective means (circles $\pm \mathrm{sd}$ ) from morning until afternoon. The dotted line in $(\mathrm{j}$ ) reflects a power fit to all results except those assumed to be photoinhibited, while the dashed circle encloses data of obviously photoinhibited leaves. All measurements were performed $34 \mathrm{~d}$ after sowing and $4 \mathrm{~d}$ after slight rain $(3 \mathrm{~mm})$.

The diurnal variations in $J_{\mathrm{CO} 2}$ and $J_{\mathrm{H} 2 \mathrm{O}}$ or $g_{\text {st }}$, respectively, only marginally affected both the instantaneous (Figure 2g) and the intrinsic water use efficiencies of hemp leaves (Figure 2h). In both cases, variability of values largely increased after noon. Nevertheless, while $W U E_{\text {inst }}$ tended to decline during the course of the day, the majority $W U E_{\text {intrinsic }}$ values increased with the pronounced reduction of $g_{\text {st }}$ during the progressing day.

\subsection{Plant Growth Analyses}

Although variability of results was high, plants of 'Santhica 27 ' tended to be taller than those of 'Ivory' (Figure 3a). While relative growths rates declined approx. $40 \mathrm{~d}$ and $60 \mathrm{~d}$ after sowing in 'Santhica 27' and in 'Ivory', plants height growth ceased after approx. $90 \mathrm{~d}$ in plants of both cultivars 
(Figure 3a). In contrast, seasonal dynamics of mean total leaf area per plant (Figure 3b), number of plants per $\mathrm{m}^{2}$ ground area (Figure 3c) and, thus, leaf area index (Figure 3d), pronouncedly differed between the plants of both cultivars. Although average leaf area of 'Ivory' plants was larger at an early growth stage, it rapidly declined with progressing season after approx. $70 \mathrm{~d}$ after sowing (Figure $3 \mathrm{~b}$ ). Seasonal changes in leaf area per plant were much slower for 'Santhica 27' and mean leaf area less than that of 'Ivory' until mid-growth period. In addition, the plant density per $\mathrm{m}^{2}$ (Figure 3c) for 'Ivory' was less than half that of 'Santhica 27 '. On the other hand, the number of plants per unit ground area continuously and pronouncedly declined in the latter cultivar. As a consequence of these changes, $L A I$ started to decline approx. $70 \mathrm{~d}$ after sowing for 'Ivory', when that of 'Santhica 27' still increased until approx. $80 \mathrm{~d}$ after sowing. It also remained pronouncedly higher for the rest of the growing season (Figure 3d).

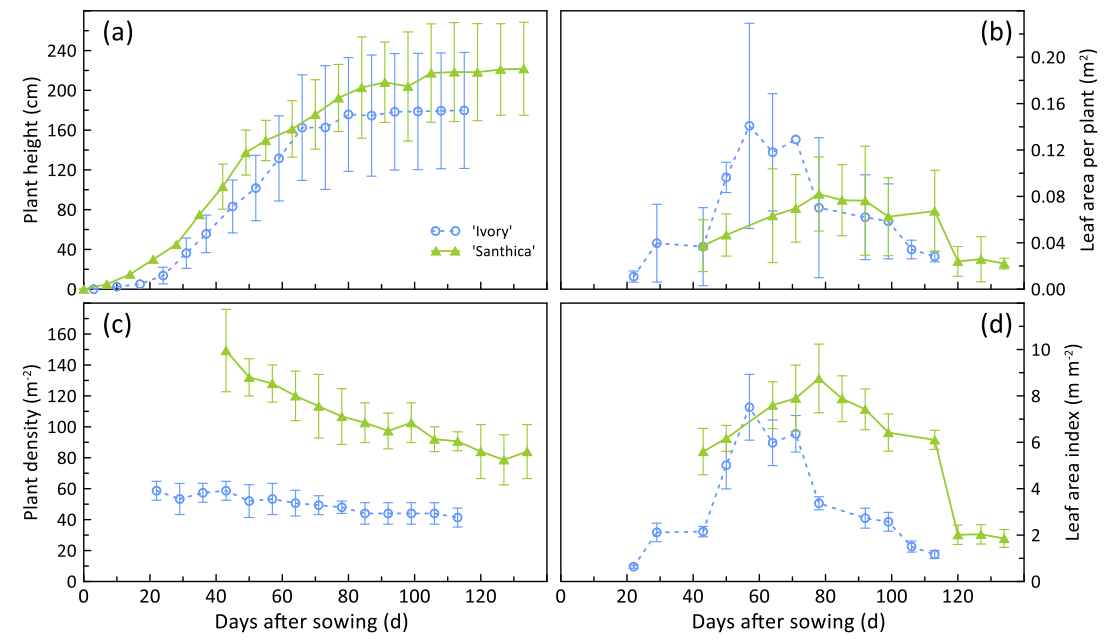

Figure 3. Seasonal growth dynamics of 'Ivory' (circles) and 'Santhica 27' (triangles) plants as indicated by (a) means of non-destructive plant height, (b) total leaf area per plants, (c) plant density and (d) leaf area index.

\subsection{Seasonal Variation of Photosynthesis and Transpiration}

While the average net carbon gain of 'Ivory' plants continued to increase during the initial growing phase, reaching a maximum approx. $60 \mathrm{~d}$ after sowing (Figure 4a) that of 'Santhica 27' showed a broad optimum beyond day 35 after sowing. Irrespective of the cultivar, net carbon gain declined with further plant development and progressing season, reaching similar low mean $J_{\mathrm{CO} 2}\left(<5 \mu \mathrm{mol} \mathrm{m} \mathrm{m}^{-2} \mathrm{~s}^{-1}\right)$ after approx. $80 \mathrm{~d}$ of growth. Generally similar dynamics were valid for transpiration for plants of both cultivars (Figure $4 \mathrm{~b}$ ). Nevertheless, $J_{\mathrm{H} 2 \mathrm{O}}$ of 'Ivory' plants tended to be higher during the mid growth season.

Seasonal variations in stomatal conductance were highly similar for plants of both cultivars (Figure 4c) and closely followed the dynamics observed for $J_{\mathrm{CO} 2}$ of 'Ivory'. As a result, the ratio of internal to ambient $\mathrm{CO}_{2}$ mole fraction of these plants was almost constant during the entire growth season (Figure 4d). In contrast, that of 'Santhica 27' plants increased until the drop of photosynthetic performance in the late developmental phase. The latter indicated that the effects of stomatal limitations on net $\mathrm{CO}_{2}$ uptake, observed in the early season, were replaced by a true reduction of $\mathrm{CO}_{2}$ fixation ability in 'Santhica 27 '.

Relating $J_{\mathrm{CO} 2}$ and $J_{\mathrm{H} 2 \mathrm{O}}$ to the respective day length, each corrected for nighttime respiration and transpiration, provides a rough estimation of the total amounts of $\mathrm{CO}_{2}$ gained $\left(B_{\mathrm{CO} 2}\right)$ and $\mathrm{H}_{2} \mathrm{O}\left(B_{\mathrm{H} 2 \mathrm{O}}\right)$ lost per day. For plants of 'Santhica 27', this yielded means of $B_{\mathrm{CO} 2}$ and $B_{\mathrm{H} 2 \mathrm{O}}$ of $0.21 \mathrm{~mol} \mathrm{~m}^{-2} \mathrm{~d}^{-1}$ and $41 \mathrm{~mol} \mathrm{~m}^{-2} \mathrm{~d}^{-1}$, with the maxima being 1.10 and $197 \mathrm{~mol} \mathrm{~m}^{-2} \mathrm{~d}^{-1}$. For plants of 'Ivory', ${ }^{\text {av }} B_{\mathrm{CO} 2}$ and ${ }^{\text {av }} B_{\mathrm{H} 2 \mathrm{O}}$ were 0.22 and $48 \mathrm{~mol} \mathrm{~m}^{-2} \mathrm{~d}^{-1},{ }^{\max } B_{\mathrm{CO} 2}$ and ${ }^{\max } B_{\mathrm{H} 2 \mathrm{O}}$ being 1.81 and $250 \mathrm{~mol} \mathrm{~m}^{-2} \mathrm{~d}^{-1}$. 

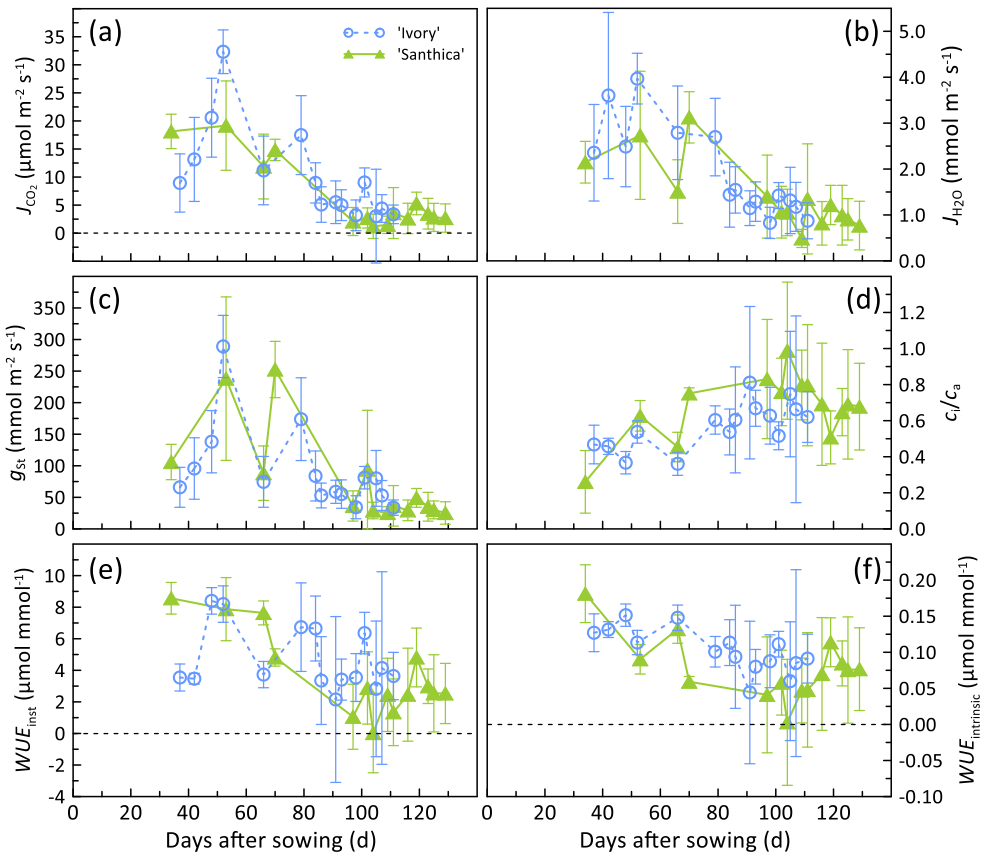

Figure 4. (a) Rates of net $\mathrm{CO}_{2}$ exchange $\left(J_{\mathrm{CO} 2}\right)$, (b) transpiration $\left(J_{\mathrm{H} 2 \mathrm{O}}\right)$, (c) stomatal conductance for water vapor transfer $\left(g_{\mathrm{st}}\right)$, (d) ratio of internal to ambient $\mathrm{CO}_{2}$ mole fraction $\left(c_{\mathrm{i}} / c_{\mathrm{a}}\right)$, (e) instantaneous $\left(W U E_{\text {inst }}\right)$ and (f) intrinsic (WUE $\left.E_{\text {intrinsic }}\right)$ water use efficiencies of 'Ivory' (open circles) and 'Santhica 27' (closed triangles) plants during the course of the growing season.

This all resulted in a decline in both the instantaneous (Figure 4e) and the intrinsic (Figure 4f) water use efficiency in plants of 'Santhica 27'. In 'Ivory' plants, this variation was much less distinct, if valid at all. Nevertheless, the variability of the water use efficiencies largely increased during the late developmental phase as the performance of differentially old leaves pronouncedly diverged in plants of both cultivars. Older leaves started to senesce resulting in net $\mathrm{CO}_{2}$ losses, while younger leaves still actively assimilated.

A plot of net $\mathrm{CO}_{2}$ exchange rates over stomatal conductance for water vapor transfer helps to evaluate the potential effects of stomata on carbon gain (Figure 5). In plants of both cultivars, the two parameters were closely related, particularly during the active growth phase. Here, 'Ivory' plants clearly showed the higher net photosynthetic activity at nearly the same stomatal conductance. With progressing development and season, both parameters declined, but $g_{\text {st }}$ of 'Santhica 27' plants was obviously lower during the senescence phase than that of 'Ivory'.

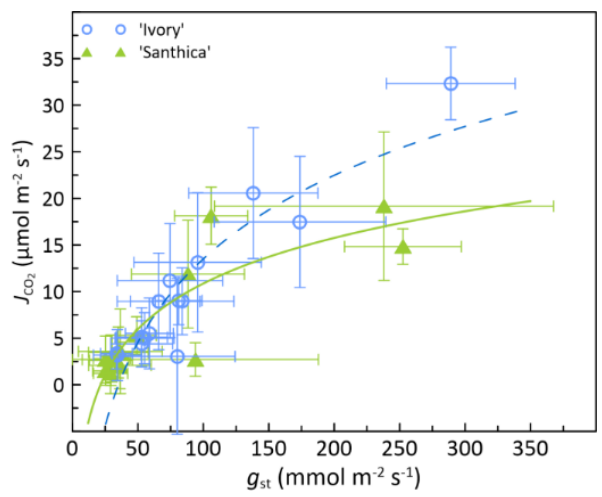

Figure 5. Plot of net $\mathrm{CO}_{2}$ exchange rates $\left(J_{\mathrm{CO} 2}\right)$ over stomatal conductance for water vapor transfer $\left(g_{\mathrm{st}}\right)$ obtained during the course of the growing season on plants of 'Ivory' and of 'Santhica 27'. The lines indicate the respective polynomial fits applied to the entire data sets. 


\subsection{Yield Analysis}

As expected from growth dynamics and LAI (cf. Figure 3), 'Santhica 27' plants yielded higher mean fresh $\left(Y_{\mathrm{FM}}\right)$ and dry masses $\left(Y_{\mathrm{DM}}\right)$ per ha than those of 'Ivory', although the differences were statistically not significant (Table 1). This was also valid for the respective stem components, i.e., straw and bast, in that year.

Table 1. Fresh mass- $\left(Y_{\mathrm{FM}}\right)$ and dry mass $\left(Y_{\mathrm{DM}}\right)$-based yields per production area and yearly means of total fresh mass $\left(F M_{\text {plant }}\right)$, and straw dry mass $\left(D M_{\text {straw }}\right)$ as well as bast fresh $\left(F M_{\text {bast }}\right)$ and dry mass $\left(D M_{\text {bast }}\right)$ produced by 'Ivory' and 'Santhica 27 ' plants $\left(\mathrm{t} \mathrm{ha}^{-1}\right)$ on the experimental area. Same superscripts indicated insignificant differences between means of the respective parameters.

\begin{tabular}{|c|c|c|c|c|c|}
\hline Cultivar & $\begin{array}{c}Y_{\mathrm{FM}} \\
\left(\mathrm{t} \mathbf{h a}^{-1}\right)\end{array}$ & $\begin{array}{c}Y_{D M} \\
\left(t h^{-1}\right)\end{array}$ & 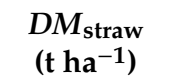 & $\begin{array}{l}F M_{\text {bast }} \\
\left(\mathrm{t} \mathrm{ha}^{-1}\right)\end{array}$ & $\begin{array}{l}D M_{\text {bast }} \\
\left(t \mathbf{h}^{-1}\right)\end{array}$ \\
\hline 'Ivory' & $14.4 \pm 6.3^{a}$ & $10.0 \pm 3.9^{b}$ & $8.8 \pm 3.4^{\mathrm{c}}$ & $4.2 \pm 1.9^{\mathrm{d}}$ & $2.1 \pm 0.9^{\mathrm{e}}$ \\
\hline 'Santhica' & $24.5 \pm 10.3^{a}$ & $17.9 \pm 6.3^{b}$ & $16.0 \pm 5.1^{c}$ & $6.3 \pm 2.6^{d}$ & $2.8 \pm 0.8^{\mathrm{e}}$ \\
\hline
\end{tabular}

\section{Discussion}

\subsection{Yield Responses}

Although once an important fiber crop, hemp lost much importance during the last century and was largely displaced by cotton and synthetic fibers. Between 1982 and 1996, hemp production was, furthermore, not possible in Germany and many other countries due to legal regulations to prevent the danger of drug abuse. During recent years, however, production of industrial hemp experienced a fascinating rebirth $[2,15,33]$. This partially resulted from the rising awareness for the ecological problems associated with e.g., cotton production, i.e., the intensive need for pesticides and for irrigation [34].

Hemp is known for its modest water demands, at least if compared to cotton, maize or sorghum $[15,17,35,36]$. On the other hand, several, but not all studies indicated that without irrigation, fiber yield of hemp is less consistent than e.g., that of flax and kenaf in semi-arid regions with low rainfall [35,37]. Thus, Fernando et al. [2] proposed to allocate hemp production with its relative higher water demands (than flax or kenaf) to areas with more frequent precipitation.

However, particularly the very recent years 2018 and 2019 impressively proved that even the moist-climatic northern parts of Central Europe may be prone to long-term periods without sufficient precipitation during summer months in future. Consequently, evaluation of the physiological responses of hemp plants in general and of distinct hemp cultivars in particular are no longer solely academic but of high practical relevance.

In the present study, plants of both 'Ivory' and of 'Santhica 27' were grown exclusively under rain-fed conditions (except the initial onetime $10 \mathrm{~mm}$ during the germination phase) at constantly high to very high daytime temperatures, low air humidity, very high solar radiation input and scarce precipitation during the entire season. Nevertheless, despite their different growth patterns, plants of both cultivars developed and yielded as previously described as normal for hemp [12,19,38]. In this context, de Meijer and Keizer [39] highlighted that overall growth patterns pronouncedly and specifically vary between early and late cultivar. These authors reported that the day of anthesis is not associated with a certain state of stem elongation. Only in early flowering accessions, stem length growth was greater after anthesis, but elongation always stopped at seed maturity.

Plants of 'Ivory' yielded a total mean stem mass of $8.7 \mathrm{t} \mathrm{ha}^{-1}$ as studied in various European countries in 2015/2016 [38]. Those of 'Santhica 27' produced $9.7 \mathrm{t} \mathrm{ha}^{-1}$ (e.g., 8.3-10.4 $\mathrm{t} \mathrm{ha}^{-1}$ ) and maximal stem heights of $1.9 \mathrm{~m}$ at two sites in Belgium [40]. Under optimal conditions in Latvia [41], however, it yielded $18.6 \mathrm{t} \mathrm{ha}^{-1}$ at a maximal stem height of $2.3 \mathrm{~m}$. Similar stem length (2.3-2.8 m), but lower stem yields (4.0-8.3 t ha ${ }^{-1}$ ) were reported for 'Santhica 27' grown 2004 in the Mediterranean environment of Central Italy [12]. In Southern Italy, stem yield was low $\left(6.0 \mathrm{t} \mathrm{ha}^{-1}\right)$ for 'Chameleon', the ancestor 
of 'Ivory', out of four tested dioecious cultivars [19]. Interestingly, in the latter study, no difference in the length of the germination phase among different cultivars was reported. Nevertheless, life cycle of 'Chameleon' plants was relatively short, and its plant density low at harvest, as found in the present investigation. In the same investigation, a $20 \%$-reduction of whole plant and stem dry mass yield and a $30 \%$ shorter stem length of droughted $(25 \%$ replenishment of potential maximum crop evapotranspiration, ETm) compared to fully-irrigated plants was found at final harvest for the monoecious French cultivar 'Futura 75' [19].

Several reports $[19,42]$ pointed out that temperatures close to $40{ }^{\circ} \mathrm{C}$, and above, may impede the development of hemp plants. Mean maximum daytime temperatures certainly relatively often approached this "limit" in the present experiments. Nevertheless, growth reduction due to harsh climatic conditions, further intensified by the low precipitation during the entire plant development, had less negative effects on stem yield of both cultivars developed in Central-Northern Europe, than the production environment in Southern Europe, even under irrigation [19,38]. The reasons for this difference in the growth responses to the distinct environmental conditions are by far not clear. It may be related to the higher sensitivity of their physiological processes to a combination of water shortage and high temperatures $[15,19]$.

It was reported that combined drought and high temperatures could accelerate flowering [42,43], but generally delays plant growth and fiber maturation [44]. In contrast, Schäfer and Honermeier [45] reported that hemp plants ripen earlier and their stem height and diameter were lower and their fibers layers thinner in dry years.

\subsection{Diurnal Gas Exchange of 'Santhica 27' Plants}

On cloudless days with high radiation input, young plants of 'Santhica 27' showed a one-peaked diurnal gas exchange pattern with high rates of net $\mathrm{CO}_{2}$ uptake and transpiration primarily before noon. This closely reflected results obtained for canopy gas exchange on container grown droughted $50 \mathrm{~d}$ old 'Futura $75^{\prime}$ plants (50\% of regular irrigation [21]). In this study [21], gas exchange of well-watered plants in the container was high and nearly constant $\left(J_{\mathrm{CO} 2}\right.$ approx. $31 \mu \mathrm{mol} \mathrm{m}{ }^{-2} \mathrm{~s}^{-1} ; J_{\mathrm{H} 2 \mathrm{O}}$ approx. $11 \mathrm{mmol} \mathrm{m}^{-2} \mathrm{~s}^{-1}$ ) most of the light period [21]. In the presented field experiment (and the droughted plants in [21]), however, that of both 'Santhica 27' and 'Ivory' plants was pronouncedly reduced at low stomatal conductance in the afternoon, when both leaf temperatures and water vapor partial pressure deficits were high. In well-watered plants, distinct diurnal gas exchange patterns occur frequently and seem to be species-specific [46]. In this case, gas exchange closely reflects the diurnal course of PPFR with high rates of net photosynthesis and transpiration at midday at least at moderate temperatures. In addition, stomatal conductance then closely correlates with net photosynthesis assumingly to balance between water loss and carbon gain [46].

It is well established since decades that, under natural conditions, environmental constraints may pronouncedly affect the diurnal patterns of gas exchange [47-49]. High radiation, temperature and water vapor partial pressure deficit $(\Delta \mathrm{w})$ may typically induce the so-called midday depression of gas exchange ([50] and literature cited therein), while particularly additional water deficit [51,52], but also leaf aging, may further eliminate the afternoon peak $[53,54]$ as observed here for the hemp plants. The increase in $\Delta \mathrm{w}$ could also directly affect leaf conductance, not necessarily mediated through changes in leaf water potential $[50,55]$.

When leaf temperature exceeded $30^{\circ} \mathrm{C}$ and leaf conductance was low $\left(<50 \mathrm{mmol} \mathrm{m}^{-2} \mathrm{~s}^{-1}\right)$ during noon, net $\mathrm{CO}_{2}$ uptake rates declined and even $\mathrm{CO}_{2}$ losses occurred in older leaves. This, in turn, resulted in the large overall variation of this gas exchange parameter. Such effect was expected from the measurement strategy (see Materials and Methods) and can easily be explained by the fact that leaves of various age classes were examined to closely monitor the responses of the entire plants.

High carbon gain in all leaves was restricted to the earlier hours of the day when leaf temperature and $\Delta \mathrm{w}$ were low. During the rest of the light period, significant net carbon loss was observed, which varied with leaf temperature by nearly the same amounts in old and young leaves. Thus, heat and high 
PPFR synergistically resulted in a down-regulation of photosynthetic activity and changes in net $\mathrm{CO}_{2}$ exchange were not well correlated with PPFR. The reduction of the net $\mathrm{CO}_{2}$ uptake and the final $\mathrm{CO}_{2}$ release in older leaves also indicated that both photochemistry and biochemistry of photosynthesis were directly inhibited due to photoinhibition $[50,56,57]$. This non-stomatal inhibition is induced by the high incident radiation, is independent of changes in stomatal conductance, is enhanced by high temperatures and let the $c_{\mathrm{i}} / c_{\mathrm{a}}$ ratio rise in the respective leaves $[49,56,58,59]$. The increase in $\Delta \mathrm{w}$ observed during the course of that day could not be responsible for the observed variation in the degree of photoinhibition. Nevertheless, the latter was certainly influenced by both mean leaf temperature at saturating light period and $\Delta \mathrm{w}$ in the respective leaves. On the other hand, photosynthesis was not or only slightly affected in most other leaves, even under these unfavorable climatic conditions and post-noon $\mathrm{CO}_{2}$ uptake was merely limited by the increased diffusion resistance. At the constant ambient $\mathrm{CO}_{2}$, this, however, induced a decline in $c_{\mathrm{i}} / c_{\mathrm{a}}$. All the above effects let also both instantaneous and intrinsic WUE vary pronouncedly during this period of the day.

As a consequence of the co-occurrence of both opposite effects, the variation in this ratio largely increased after noon. Thus, for further analyses of the overall changes in photosynthesis and transpiration, care was taken that the measurements were performed in the morning. This also guaranteed that maximal net $\mathrm{CO}_{2}$ gain at the maximal stomatal conductance at the lowest possible variability was obtained.

\subsection{Seasonal Variation of Gas Exchange Parameters}

The variations of the seasonal gas exchange parameters may nicely reflect the differences in maturation speed between both cultivars. After an obviously initial slow exponential increase in the daily maximal $\mathrm{CO}_{2}$ gain during the growth phase, plants of the early maturing 'Ivory' showed a distinct and pronounced maximum of photosynthesis at approx. $52 \mathrm{~d}$ after sowing, followed by a relatively fast decline. According to Cosentino et al. [13], for plants of the early-mature 'Chameleon', the "ancestor" of 'Ivory', this growth duration may characterize the end of flowering and, thus, the beginning of the senescence [60].

This interpretation is further substantiated by the seasonal changes in the number of leaves per plant and the $L A I$, but not necessarily by stem length. In this context, de Meijer and Keizer [39] impressively indicated that stem length growth is not a meaningful indicator of the phenological stage of hemp. The decline in photosynthetic competence is accompanied by a reduction of stomatal conductance; it is, however, not a consequence of stomatal limitation as could be deduced from the clear though minimal increase in the $c_{\mathrm{i}} / c_{\mathrm{a}}$ ratio $[58,59]$.

Seasonal variations in gas exchange of plants of the mid-mature 'Santhica 27 ' are, on the other hand, characterized by lower (compared to 'Ivory') but more or less constant $\mathrm{CO}_{2}$ uptake until at least $70 \mathrm{~d}$ after sowing. This time nicely fits the beginning of senescence reported earlier for this cultivar [12,40]. Again, the start of the decline in net photosynthetic carbon gain was also reflected by the changes in $L A I$, but less so by the variation in total leaf area per plant. Also, stem length growth ceased later than the senescence of 'Santhica 27 ' hemp started. Interestingly, the $c_{\mathrm{i}} / c_{\mathrm{a}}$ ratio increased significantly earlier in 'Santhica 27' than in 'Ivory' plants. This indicated that the variation in photosynthetic competence was not mediated by stomatal limitations because this would have resulted in a decline of this parameter [61]. In addition, both the instantaneous and the intrinsic water use efficiencies decreased with progressing season, but to a larger degree in 'Santhica 27' than in 'Ivory'. Nevertheless, this indicates that $\mathrm{CO}_{2}$ gain is faster restricted with the beginning of senescence than is transpirational water loss. From all these results, plant development more pronouncedly affected seasonal changes in net carbon gain than water limitations. Due to the distinct influence of stomata on net $\mathrm{CO}_{2}$ exchange plants, it was not surprising that the intrinsic water use efficiency did only change when senescence became relevant. Before this, the calculated $W U E_{\text {inst }}$ and $W U E_{\text {intrinsic }}$ closely reflected those previously reported by Tang et al. [21]. These authors found that $W U E_{\text {inst }}$ increased from 4.2 in well-watered to approx. $7.5 \mathrm{mmol} \mathrm{mol}^{-1}$ in droughted hemp plants after $13 \mathrm{~d}$ of withholding water. 
Interestingly, seasonal maximum of mean net $\mathrm{CO}_{2}$ uptake rates recorded for 'Ivory' plants $\left(32.3 \pm 3.9 \mu \mathrm{mol} \mathrm{m} \mathrm{m}^{-2} \mathrm{~s}^{-1}\right)$ nicely reflects the mean daily canopy $J_{\mathrm{CO} 2}$ of approx. $31 \mu \mathrm{mol} \mathrm{m} \mathrm{m}^{-2} \mathrm{~s}^{-1}$ reported for well-watered plants of 'Futura 75' [5,21]. Although max ${ }_{\mathrm{CO} 2}$ of 'Santhica 27' plants was significantly lower $\left(19.2 \pm 8.0 \mu \mathrm{mol} \mathrm{m}^{-2} \mathrm{~s}^{-1}\right)$, net $\mathrm{CO}_{2}$ uptake rates of plants of both cultivars studied in this field trail fit well to the range (ca. 14 to $25 \mu \mathrm{mol} \mathrm{m}{ }^{-2} \mathrm{~s}^{-1}$ ) measured in the laboratory on plants for various other cultivars at ambient $\mathrm{CO}_{2}$, light saturation and optimal temperature of $25^{\circ} \mathrm{C}$ to $30^{\circ} \mathrm{C}[22,24,62]$. Furthermore, mean maximum net $\mathrm{CO}_{2}$ gain rates obtained here for droughted 'Ivory' and 'Santhica $27^{\prime}$ ' plants well before noon were obvious close to the optimum for hemp, also measured at its temperature optimum $[5,19,22,24,62]$.

In this context, Tang et al. [21] reported mean maximum total daily carbon gain and transpirational water losses of approx. 1.1 and $250 \mathrm{~mol} \mathrm{~m}^{-2} \mathrm{~d}^{-1}$, which is very close to the results estimated for plants of 'Ivory'. After withholding irrigation [21], these rates rapidly, within only $4 \mathrm{~d}$, declined to 0.3 and $40 \mathrm{~mol} \mathrm{~m}^{-2} \mathrm{~d}^{-1}$ and remained almost constant at these low rates until the end of the experiment. Thus, it is highly plausible that, besides plant development, heat and/or high PPFR contribute much more to the photosynthetic limitation than dehydration itself. Indeed, under natural and artificial drought conditions, photosynthetic capacity seems to be affected only at very serious leaf water deficits [53,54,63-65]. Otherwise, stomatal inhibition of $\mathrm{CO}_{2}$ gain seems to be the primary and initial control factor, as also may be reflected by the close relationship between both parameters observed for plants of both cultivars in the present study and reported by others (e.g., [21,50,64]. This, however, is quite obvious because of the direct control of stomatal conductance by soil water content, mediated by roots and the abscisic acid (ABA) concentration in the xylem as impressively shown by Bates and Hall [66] almost 40 years ago [67-70]. In this context, Gao et al. [13] pointed out that ABA mediated stomatal but also plant developmental effects are important in the drought stress response of hemp. In general, understanding stomatal regulation is fundamental to predicting the impact of changing environmental conditions on vegetation [70]. For hemp growth, especially, understanding the relationship between drought and water use is essential.

From the above it is obvious that $\mathrm{CO}_{2}$ gain is under comprehensive stomatal control in plants of both cultivars. Stomata rapidly and pronouncedly respond to all changes in the climatic conditions. Despite this common feature, overall physiological and yield responses to the harsh climatic and soil water conditions prevailing during this growing season were indeed very different. In 'Ivory' plants, the tendentially higher stomatal limitations led to higher water use efficiency and thus water saving.

After some delay, 'Ivory' plants realized high rates of $\mathrm{CO}_{2}$ uptake (higher than that of 'Santhica $27^{\prime}$ ). This allows establishing a large leaf area per plant relatively early in the growing season. On the other hand, the clear reduction of the photosynthetic performance and growth success with the early onset of senescence shortened the total productive period. In terms of production, this should lead to shorter growth duration and earlier harvest. Maxima of $\mathrm{CO}_{2}$ gain and total leaf area per plant of 'Santhica 27', however, were generally reached earlier and remained approx. constant for a much longer time, although at lower rates and lower leaf areas. This and the higher germination success of 'Santhica 27 ' finally resulted in nearly twice the yield compared to 'Ivory'.

From the ecological point of view, plants of 'Ivory' with their 'optimistic' strategy of high carbon gains in the mid-season resulted in a somewhat better seasonal water use and needed at shorter time until harvest. The "pessimistic" 'Santhica 27' plants, however, needed a somewhat longer growth period, but finally also had a higher yield at an obvious higher water demand.

According to Cosentino et al. [13], planning sowing time to circumvent unfavorable climatic conditions for vegetative growth may further lessen water demands of hemp. This however, is not necessarily and easily possible for hemp production in northern Central Europe situations due to the generally shorter growing season. Even here, more regions might be characterized by poor rainfall and high temperatures during late spring and summer and, thus, hemp will need irrigation [71] with further climatic changes. 


\section{Conclusions}

In this field study, the actual rates of net photosynthesis and transpiration, its potential stomatal regulation, water use efficiencies and the yield performance of plants of two monoecious hemp cultivars were evaluated during a hot and dry growing season to get closer information on their respective physiological and yield performance. This allows predicting the usability of these "northern Central Europe" hemp cultivars under potential future harsh low-water availability production conditions.

Irrespective of the cultivar, stomatal conductance rapidly responded to variations in the climatic conditions. This always resulted in a pronounced stomatal control of $\mathrm{CO}_{2}$ gain. Stomatal limitations tended to be higher in 'Ivory' plants, finally resulting in somewhat higher intrinsic water use efficiency (and, so less clear, of $W U E_{\text {inst }}$ ).

Plants of both cultivars obviously used different acclimation strategies to cope with the climatic and soil water conditions. After delayed germination, 'Ivory' plants established high $\mathrm{CO}_{2}$ uptake rates and large leaf areas per plant relatively early in the growing season but photosynthesis and growth was reduced with the relative early onset of senescence (compared to 'Santhica 27'). In contrast, plants of 'Santhica 27' earlier reached low but long-term constant $\mathrm{CO}_{2}$ gain and leaf area per plant, and finally established a higher final plant density. Consequently, yield of 'Santhica 27' was nearly twice that of 'Ivory'. Plants of 'Ivory' with their 'optimistic' strategy of high carbon gains during a shorter season resulted in a somewhat better water use but lower yield than the 'pessimistic' 'Santhica 27' plants.

Obviously, these hemp cultivars can be successfully grown without continuous irrigation in northern Central Europe even under unusual hot and dry conditions, without largely affecting overall yield and quality. Nevertheless, low basic irrigation during the phase of seed germination is advantageous to guarantee even sprouting and seedling establishment.

Author Contributions: Conceptualization, H.-J.G., I.F., K.D. and W.B.H.; methodology, H.-J.G., I.F., K.D. and W.B.H.; validation, I.F., H.-J.G. and W.B.H.; formal analysis, I.F., H.-J.G. and W.B.H.; investigation, I.F. and H.-J.G.; resources, H.-J.G. and W.B.H.; data curation, I.F., H.-J.G. and W.B.H.; writing-original draft preparation, W.B.H.; writing-review and editing, W.B.H., K.D., and H.-J.G.; visualization, W.B.H.; supervision, W.B.H., K.D., and H.-J.G. All authors have read and agreed to the published version of the manuscript.

Funding: This research received no external funding.

Acknowledgments: The authors thank B. Trost and his team (ATB) for their perfect help with growing the plants and Craig E. Martin, Lawrence, USA, for polishing the English.

Conflicts of Interest: The authors declare no conflict of interest.

\section{References}

1. García-Tejero, I.F.; Durán-Zuazo, V.H.; Pérez-Álvarez, R.; Hernández, A.; Casano, S.; Morón, M.; Muriel-Fernández, J.L. Impact of plant density and irrigation on yield of hemp (Cannabis sativa L.) in a Mediterranean semi-arid environment. J. Agric. Sci. Technol. 2014, 16, 887-895.

2. Fernando, A.L.; Duarte, M.P.; Vatsanidou, A.; Alexopoulou, E. Environmental aspects of fiber crops cultivation and use. Ind. Crops Prod. 2015, 68, 105-115. [CrossRef]

3. Struik, P.; Amaducci, S.; Bullard, M.; Stutterheim, N.; Venturi, G.; Cromack, H. Agronomy of fibre hemp (Cannabis sativa L.) in Europe. Ind. Crops Prod. 2000, 11, 107-118. [CrossRef]

4. Tang, K.; Struik, P.; Yin, X.; Thouminot, C.; Bjelková, M.; Stramkale, V.; Amaducci, S. Comparing hemp (Cannabis sativa L.) cultivars for dual-purpose production under contrasting environments. Ind. Crops Prod. 2016, 87, 33-44. [CrossRef]

5. Tang, K.; Struik, P.C.; Amaducci, S.; Stomph, T.-J.; Yin, X. Hemp (Cannabis sativa L.) leaf photosynthesis in relation to nitrogen content and temperature: Implications for hemp as a bio-economically sustainable crop. GCB Bioenergy 2017, 9, 1573-1587. [CrossRef]

6. Tang, K.; Struik, P.; Yin, X.; Calzolari, D.; Musio, S.; Thouminot, C.; Bjelková, M.; Stramkale, V.; Magagnini, G.; Amaducci, S. A comprehensive study of planting density and nitrogen fertilization effect on dual-purpose hemp (Cannabis sativa L.) cultivation. Ind. Crops Prod. 2017, 107, 427-438. [CrossRef] 
7. Finnan, J.; Styles, D. Hemp: A more sustainable annual energy crop for climate and energy policy. Energy Policy 2013, 58, 152-162. [CrossRef]

8. Van der Werf, H.M.G.; Mathijssen, E.W.J.M.; Haverkort, A.J. The potential of hemp (Cannabis sativa L.) for sustainable fibre production: A crop physiological appraisal. Ann. Appl. Biol. 1996, 129, 109-123. [CrossRef]

9. Bouloc, P.; van der Werf, H.M.G. The role of hemp in sustainable development. In Hemp: Industrial Production and Uses; Bouloc, P., Allegret, S., Arnaud, L., Eds.; CABI eBook: Wallingford, UK, 2013; pp. $278-289$. [CrossRef]

10. Barth, M.; Carus, M. Carbon Footprint and Sustainability of Different Natural Fibres for Biocomposites and Insulation Material; Nova-Institut GmbH: Hürth, Germany, 2015. Available online: http://news.bio-based.eu/media/ 2015/04/15-04-20_PR_Carbon-Footprint-of-Natural-Fibres_nova.pdf (accessed on 3 July 2020).

11. Meijer, W.J.M.; van der Werf, H.M.G.; Mathijssen, E.W.J.M.; van den Brink, P.W.M. Constraints to dry-matter production in fibre hemp (Cannabis sativa L.). Eur. J. Agron. 1995, 4, 109-117. [CrossRef]

12. Campiglia, E.; Radicetti, E.; Mancinelli, R. Plant density and nitrogen fertilization affect agronomic performance of industrial hemp (Cannabis sativa L.) in Mediterranean environment. Ind. Crops Prod. 2017, 100, 246-254. [CrossRef]

13. Gao, C.; Cheng, C.; Zhao, L.; Yu, Y.; Tang, Q.; Xin, P.; Liu, T.; Yan, Z.; Guo, Y.; Zang, G. Genome-wide expression profiles of hemp (Cannabis sativa L.) in response to drought stress. Int. J. Genom. 2018, 13, 3057272. [CrossRef] [PubMed]

14. Petit, J.; Salentijn, E.M.J.; Paulo, M.-J.; Claire Thouminot, C.; Bert Jan van Dinter, B.J.; Magagnini, G.; Gusovius, H.-J.; Tang, K.; Amaducci, S.; Wang, S.; et al. Genetic variability of morphological, flowering, and biomass quality traits in hemp (Cannabis sativa L.). Front. Plant Sci. 2020, 11, 102. [CrossRef] [PubMed]

15. Amaducci, S.; Scordia, D.; Liu, F.H.; Zhang, Q.; Goa, H.; Testa, G.; Cosentino, S.L. Key cultivation techniques for hemp in Europe and China. Ind. Crops Prod. 2015, 68, 2-16. [CrossRef]

16. Malceva, M.; Vikmane, M.; Stramkale, V. Changes of photosynthesis-related parameters and productivity of Cannabis sativa under different nitrogen supply. Environ. Exp. Biol. 2011, 9, 61-69.

17. Amaducci, S.; Amaducci, M.T.; Benati, R.; Venturi, G. Crop yield and quality parameters of four annual fibre crops (hemp, kenaf, maize and sorghum) in the North of Italy. Ind. Crops Prod. 2000, 11, 179-186. [CrossRef]

18. Bócsa, I.; Karus, M. The Cultivation of Hemp: Botany, Varieties, Cultivation and Harvesting; Hemptech: Sebastopo, CA, USA, 1998; ISBN 1886874034.

19. Cosentino, S.L.; Riggi, E.; Testa, G.; Scordia, D.; Copani, V. Evaluation of European developed fibre hemp genotypes (Cannabis sativa L.) in semi-arid Mediterranean environment. Ind. Crops Prod. 2013, 50, 312-324. [CrossRef]

20. Di Bari, V.; Campi, P.; Colucci, R.; Mastrorilli, M. Potential productivity of fibre hemp in southern Europe. Euphytica 2004, 140, 25-32. [CrossRef]

21. Tang, K.; Fracasso, A.; Struik, P.C.; Yin, X.; Amaducci, S. Water- and nitrogen-use efficiencies of hemp (Cannabis sativa L.) based on whole-canopy measurements and modeling. Front. Plant Sci. 2018, 9, 951. [CrossRef]

22. Chandra, S.; Lata, H.; Khan, I.A.; ElSohly, M.A. Photosynthetic response of Cannabis sativa L. to variations in photosynthetic photon flux densities, temperature and $\mathrm{CO}_{2}$ conditions. Physiol. Mol. Biol. Plants 2008, 14, 299-306. [CrossRef]

23. Chandra, S.; Lata, H.; Mehmedic, Z.; Khan, I.A.; ElSohly, M.A. Light dependence of photosynthesis and water vapor exchange characteristics in different high D9-THC yielding varieties of Cannabis sativa L. J. Appl. Res. Med. Aromat. Plants 2015, 2, 39-47. [CrossRef]

24. Chandra, S.; Lata, H.; Khan, I.A.; ElSohly, M.A. Temperature response of photosynthesis in different drug and fiber varieties of Cannabis sativa L. Physiol. Mol. Biol. Plants 2011, 17, 297-303. [CrossRef]

25. Köstner, B.; Surke, M.; Bernhofer, C. Klimadiagnose der Region Berlin/Barnim/Uckermark/Uecker-Randow für den Zeitraum 1951 bis 2006. 2007. Available online: https://www.researchgate.net/publication/44175675_ Klimadiagnose_der_Region_Berlin_Barnim_Uckermark_Uecker-Randow_fur_den_Zeitraum_1951_bis_ 2006 (accessed on 3 July 2020).

26. ATB. Fieldlab for Digital Agriculture. Available online: https://www.atb-potsdam.de/en/research/researchinfrastructure/fieldlab-for-digital-agriculture (accessed on 3 July 2020).

27. ATB. ATB's Research Site Marquardt. Available online: https://www.atb-potsdam.de/en/research/researchinfrastructure/soil-weather-crops (accessed on 3 July 2020). 
28. Trost, B. Site Description Research Site Marquardt Fieldlab for Digital Agriculture, Leibniz-Institut fur Agrartechnik und Bioökonomie e.V. (ATB). Available online: https://www.atb-potsdam.de/en/institute/aboutus/research-infrastructure/research-sites/equipment-and-site---description.html (accessed on 3 July 2020).

29. Hemp Variety Datasheet. Available online: https://www.ihempfarms.com/DS_Santhica27 (accessed on 3 July 2020).

30. Solomon, R.W. Free and open source software for the manipulation of digital images. Am. J. Roentgenol. 2009, 192, W330-W334. [CrossRef]

31. Von Caemmerer, S.; Farquhar, G.D. Some relationships between the biochemistry of photosynthesis and the gas exchange of leaves. Planta 1981, 153, 376-387. [CrossRef]

32. Matyssek, R.; Herppich, W.B. Physikalische Grundlagen von Transpiration, $\mathrm{CO}_{2}$-Aufnahme, Gasleitfähigkeiten und deren Bestimmungen. In Experimentelle Pflanzenökologie. Springer Reference Naturwissenschaften; Matyssek, R., Herppich, W.B., Eds.; Springer: Berlin/Heidelberg, Germany, 2017; pp. 1-30. [CrossRef]

33. Herer, J.; Bröckers, M. Die Wiederentdeckung der Nutzpflanze Hanf; Verlag Zweitausendeins: Frankfurt, Germany, 1995; ISBN 3861500590.

34. Perović, D.; Crawley, B.; Hume, I.; Hoogers, R.; Sun, D.; Uddinie, J.; Regan, P. Benchmarking Water Productivity of Australian Irrigated Cotton. Primefact 1705. NSW Department of Primary Industries, State of New South Wales, Australia. 2019. Available online: https://www.dpi.nsw.gov.au/agriculture/irrigation/ irrigation/irrigation-primefacts/benchmarking-water-productivity-of-australian-cotton-primefact (accessed on 3 July 2020).

35. Lloveras, J.; Santiveri, F.; Gorchs, G. Hemp and flax biomass and fiber production and linseed yield in Mediterranean conditions. J. Ind. Hemp 2006, 11, 3-15. [CrossRef]

36. Shareef, M.; Gui, D.; Zeng, F.; Waqas, M.; Zhang, B.; Iqbal, H. Water productivity, growth, and physiological assessment of deficit irrigated cotton on hyperarid desert-oases in northwest China. Agric. Water Manag. 2018, 206, 1-10. [CrossRef]

37. Patane, C.; Cosentino, S.L. Yield, water use and radiation use efficiencies of kenaf (Hibiscus cannabinus L.) under reduced water and nitrogen soil availability in a semi-arid Mediterranean area. Eur. J. Agron. 2013, 46, 53-62. [CrossRef]

38. MultiHemp. Deliverable 3.2 Report on the Effects of Agronomic Practices on Hemp Biomass Yield (Fibre and Seeds) and Quality. WP3-Optimisation of Hemp Cultivation and Crop Modelling. 2017. Available online: http://multihemp.eu/project/public-deliverables/ (accessed on 3 July 2020).

39. De Meijer, E.P.M.; Keizer, L.C.P. Variation of Cannabis for phenological development and stem elongation in relation to stem production. Field Crops Res. 1994, 38, 37-46. [CrossRef]

40. Faux, A.-M.; Drayea, X.; Lambert, R.; d'Andrimont, R.; Raulier, P.; Bertin, P. The relationship of stem and seed yields to flowering phenology and sex expression in monoecious hemp (Cannabis sativa L.). Eur. J. Agron. 2013, 47, 11-22. [CrossRef]

41. Sausserde, R.; Adamovics, A.; Ivanovs, S.; Bulgakov, V. Investigations into growing and harvesting industrial hemp. J. Res. Appl. Agric. Eng. 2013, 58, 150-154.

42. Amaducci, S.; Zatta, A.; Pelatti, F.; Venturi, G. Influence of agronomic factors on yield and quality of hemp (Cannabis sativa L.) fibre and implication for an innovative production system. Field Crops Res. 2008, 107, 161-169. [CrossRef]

43. Heslop-Harrison, J.; Heslop-Harrison, Y. Cannabis sativa L. In The Induction of Flowering. Some Case Studies; Evans, L.T., Ed.; MacMillan Co. Pty Ltd.: SouthMelbourne, Australia, 1969; pp. 205-206.

44. Abot, A.; Bonnafous, C.; Touchard, F.; Thibault, F.; Chocinski-Arnault, L.; Lemoine, R.; Dédaldéchamp, F. Effects of cultural conditions on the hemp (Cannabis sativa) phloem fibres: Biological development and mechanical properties. J. Compos. Mater. 2013, 47, 1067-1077. [CrossRef]

45. Schäfer, T.; Honermeier, B. Effect of sowing date and plant density on the cell morphology of hemp (Cannabis sativa L.). Ind. Crops Prod. 2006, 23, 88-98. [CrossRef]

46. Matthews, J.S.A.; Vialet-Chabrand, S.R.M.; Lawson, T. Diurnal variation in gas exchange: The balance between carbon fixation and water loss. Plant Physiol. 2017, 174, 614-623. [CrossRef]

47. Nowak, R.S.; Anderson, J.E.; Tuft, N.L. Gas exchange of Agropyron desertorum: Diurnal patterns and responses to water vapor gradient and temperature. Oecologia 1988, 77, 289-295. [CrossRef]

48. Peters, J.; Morales, D.; Jiménez, M.S. Gas exchange characteristics of Pinus canariensis needles in a forest stand on Tenerife, Canary Islands. Trees 2003, 17, 492-500. [CrossRef] 
49. Niinemets, Ü.; Keenan, T.F. Photosynthetic responses to stress in Mediterranean evergreens: Mechanisms and models. Environ. Exp. Bot. 2014, 103, 24-41. [CrossRef]

50. Herppich, M.; Herppich, W.B.; von Willert, D.J. Influence of drought, rain and artificial irrigation on photosynthesis, gas exchange and water relations of the fynbos plant Protea acaulos (L.) Reich at the end of the dry season. Bot. Acta 1994, 107, 440-450. [CrossRef]

51. Xu, D.-Q.; Shen, Y.-K. Midday depression of photosynthesis. In Handbook of Photosynthesis; Pessarakli, M., Ed.; Marcel Dekker, Inc.: New York, NY, USA, 1996; pp. 451-459.

52. Durand, M.; Brendel, O.; Buré, C.; Courtois, P.; Lily, J.B.; Granier, A.; Le Thiec, D. Impacts of a partial rainfall exclusion in the field on growth and transpiration: Consequences for leaf-level and whole-plant water-use efficiency compared to controlled conditions. Agric. For. Meteorol. 2020, 282-283, 107873. [CrossRef]

53. Herppich, W.B.; Flach, B.M.-T.; von Willert, D.J.; Herppich, M. Field investigations of photosynthetic activity, gas exchange and water potential at different leaf ages in Welwitschia mirabilis during a severe drought. Flora 1995, 191, 59-66. [CrossRef]

54. Vongcharoen, K.; Santanoo, S.; Banterng, P.; Jogloy, S.; Vorasoot, N.; Theerakulpisut, P. Diurnal and seasonal variations in the photosynthetic performance and chlorophyll fluorescence of cassava "Rayong 9" under irrigated and rainfed conditions. Photosynthetica 2019, 57, 268-285. [CrossRef]

55. Zhang, X.; Wang, Y.; Huang, G.; Feng, F.; Liu, X.; Guo, R.; Gu, F.; Hu, X.; Yang, Z.; Zhong, X.; et al. Atmospheric humidity and genotype are key determinants of the diurnal stomatal conductance pattern. J. Agron. Crop Sci. 2020, 206, 161-168. [CrossRef]

56. Herppich, W.B. Interactive effects of light and drought stress on photosynthetic activity and photoinhibition under (sub-) tropical conditions. Acta Hortic. 2000, 531, 135-142. [CrossRef]

57. Malnoë, A. Photoinhibition or photoprotection of photosynthesis? Update on the (newly termed) sustained quenching component qH. Environ. Exp. Bot. 2018, 154, 123-133. [CrossRef]

58. Brodribb, T. Dynamics of changing intercellular $\mathrm{CO}_{2}$ concentration $\left(\mathrm{c}_{\mathrm{i}}\right)$ during drought and determination of minimum functional $c_{\mathrm{i}}$. Plant Physiol. 1996, 111, 179-185. [CrossRef]

59. Tan, Z.-H.; Wu, Z.-X.; Hughes, A.C.; Schaefer, D.; Zeng, J.; Lan, G.-Y.; Yang, C.; Tao, Z.-L.; Chen, B.-Q.; Tian, Y.-H.; et al. On the ratio of intercellular to ambient $\mathrm{CO}_{2}\left(c_{\mathrm{i}} / c_{\mathrm{a}}\right)$ derived from ecosystem flux. Int. J. Biometeorol. 2017, 61, 2059-2071. [CrossRef] [PubMed]

60. Mediavilla, V.; Jorquera, M.; Schmid-Slembrouck, I. Dezimalcode für Wachstumsstadien von Hanf. Agrar. Forsch. 1999, 6, 385-392.

61. Matyssek, R.; Herppich, W.B. Ergebnisbeispiele aus Gaswechseluntersuchungen. In Experimentelle Pflanzenökologie; Springer Reference Naturwissenschaften; Matyssek, R., Herppich, W.B., Eds.; Springer: Berlin/Heidelberg, Germany, 2017; pp. 1-19. [CrossRef]

62. Chandra, S.; Lata, H.; Khan, I.A.; ElSohly, M.A. Photosynthetic response of Cannabis sativa L., an important medicinal plant, to elevated levels of $\mathrm{CO}_{2}$. Physiol. Mol. Biol. Plants 2011, 17, 291-295. [CrossRef]

63. Kaiser, W.M. Effects of water deficit on photosynthetic capacity. Physiol. Plant. 1987, 71, 142-149. [CrossRef]

64. Flexas, J.; Medrano, H. Drought-inhibition of photosynthesis in $\mathrm{C}_{3}$ plants: Stomatal and non-stomatal limitations revisited. Ann. Bot. 2002, 89, 183-189. [CrossRef]

65. Chastain, D.R.; Snider, J.L.; Choinski, J.S.; Collins, G.D.; Perry, C.D.; Jared, W.J.; Grey, T.L.; Sorensen, R.B.; van Iersel, M.; Byrd, S.A.; et al. Leaf ontogeny strongly influences photosynthetic tolerance to drought and high temperature in Gossypium hirsutum. J. Plant Physiol. 2016, 199, 18-28. [CrossRef]

66. Bates, L.M.; Hall, A.E. Stomatal closure with soil water depletion not associated with changes in bulk leaf water status. Oecologia 1981, 50, 62-65. [CrossRef]

67. Zhang, J.; Schurr, U.; Davies, W.J. Control of stomatal behaviour by Abscisic Acid which apparently originates in the roots. J. Exp. Bot. 1987, 38, 1174-1181. [CrossRef]

68. Schurr, U.; Gollan, T.; Schulze, E.-D. Stomatal response to drying soil in relation to changes in the xylem sap composition of Helianthus annuus. II. Stomatal sensitivity to abscisic acid imported from the xylem sap. Plant Cell Environ. 1992, 15, 561-567. [CrossRef]

69. Liu, F.; Jensen, C.R.; Shahanzari, A.; Andersen, M.N.; Jacobsen, S.-E. ABA regulated stomatal control and photosynthetic water use efficiency of potato (Solanum tuberosum L.) during progressive soil drying. Plant Sci. 2005, 168, 831-836. [CrossRef] 
70. Lintunen, A.; Paljakka, T.; Salmon, Y.; Dewar, R.; Riikonen, A.; Hölttä, T. The influence of soil temperature and water content on belowground hydraulic conductance and leaf gas exchange in mature trees of three boreal species. Plant Cell Environ. 2020, 43, 532-547. [CrossRef]

71. Cosentino, S.L.; Testa, G.; Scordia, D.; Copani, V. Sowing time and prediction of flowering of different hemp (Cannabis sativa L.) genotypes in southern Europe. Ind. Crops Prod. 2012, 37, 20-33. [CrossRef]

(C) 2020 by the authors. Licensee MDPI, Basel, Switzerland. This article is an open access article distributed under the terms and conditions of the Creative Commons Attribution (CC BY) license (http://creativecommons.org/licenses/by/4.0/). 